\title{
Prevalence, Incidence and Management of Alternaria Blight of Rape-Seed and Mustard (Brassica juncea L) through Resistance and Integrated Approach
}

\author{
Sandeep Gupta ${ }^{1}$, V.B. Singh ${ }^{2 *}$, A.K. Singh ${ }^{2}$, S.K. Rai ${ }^{3}$, S.K. Singh ${ }^{1}$ and M.C. Dwivedi ${ }^{4}$ \\ ${ }^{1}$ Division of Plant Pathology, SKUAST of Jammu-180009, India \\ ${ }^{2}$ RRSS, Raya, SKUAST of Jammu -181143, India \\ ${ }^{3}$ Division of Plant Breeding and Genetics, SKUAST of Jammu-180009, India \\ ${ }^{4}$ Research Farm, Chatha, SKUAST of Jammu-180009, India \\ *Corresponding author
}

\section{A B S T R A C T}

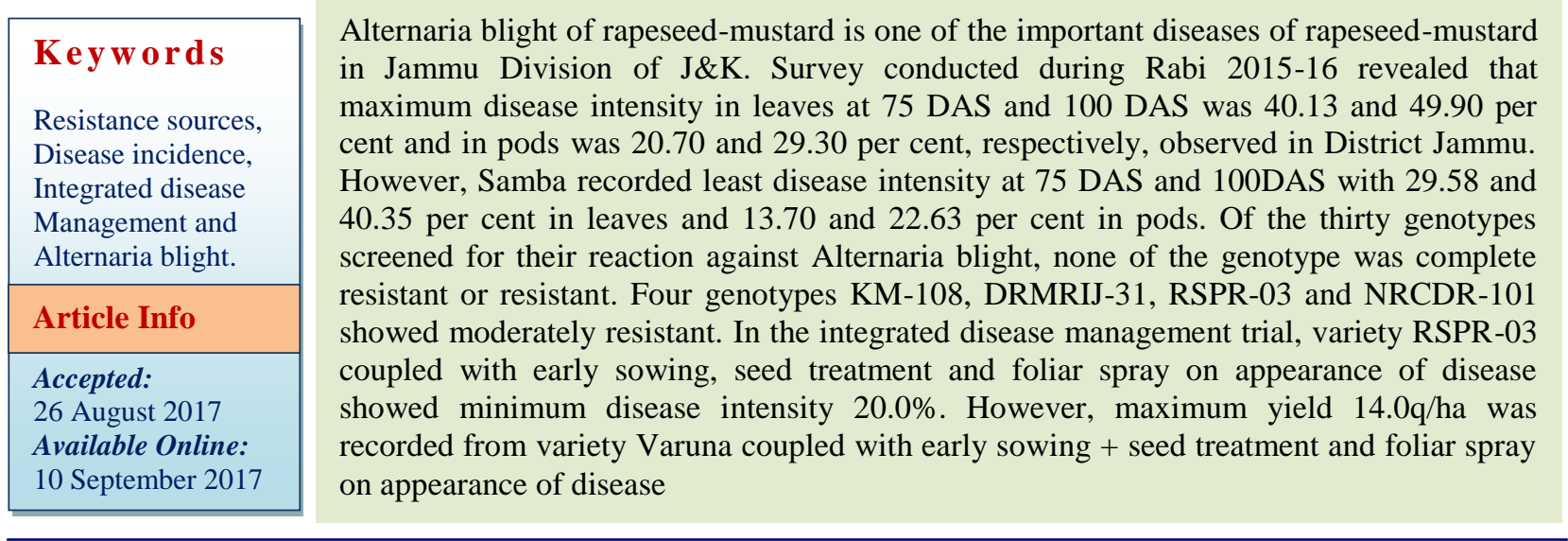

\section{Introduction}

Rapeseed-mustard (Brassica juncea $\mathrm{L}$ ) is an economically important oilseed crop of the world. In India, rapeseed-mustard is grown over in diverse agro- largest indigenous oilseed crop which contributing 32 per cent of total oilseed production in India climatic conditions ranging from north-eastern/northwestern hills to down south. It is second. Out of 63.09 million tonnes of estimated rapeseedmustard produced over 37.00 million hectares acreage with the productivity of $1850 \mathrm{~kg} / \mathrm{ha}$ in the world, in India rapeseed-mustard is cultivated in an area of 6.7 million hectares with a production of 7.90 million tonnes with productivity of $1188 \mathrm{~kg} / \mathrm{ha}$ (Anonymous, 2014). In Jammu \& Kashmir state, rapeseed mustard is cultivated in 0.059 million hectares leading to production of 0.040 million tonnes with a productivity of $682 \mathrm{~kg} / \mathrm{ha}$ (Anonymous, 2015).

Rapeseed-mustard is also exposed to various types of foliar diseases viz., white rust (Albugo candida), powdery mildew (Erysiphe 
cruciferarum), downy mildew (Peronospora parasitica) and Alternaria blight (Alternaria spp.). Among these, Alternaria blight caused by Alternaria brassicae (Berk) Sacc. And A. brassicicola (Schw.) has been reported from all the continents of the world causing severe economic yield loss (Meena et al., 2010). Further, Kolte, (1985) reported that the Alternaria blight causes an average yield loss of $46.0-47.0 \%$ in yellow sarson and 35.0 $38.0 \%$ in mustard in India. Kumar and Kolte, (2001) also observed that Alternaria blight is one of the important diseases of Brassica responsible for average yield loss of 10.0 to 70.0 per cent at different parts of the Northern India depending upon the severity. Mondal, (2008) reported yield losses upto10.0 to 40.0 per cent every year by Alternaria blight caused by $A$. brassicae in old alluvial zone of northern part of West Bengal.

The development of high yield varieties coupled with improved production technologies has led to considerable increase in the productivity of rapeseed-mustard in India during past decade. But despite this increase, the yield of oilseed brassicas in India are much below the global average and it is not able to meet the edible oil requirement for its vast population. Among different constraints in the production of rapeseed-mustard, diseases are the most important limiting factors which restrict the cultivation and decrease the productivity of these crops. In Indian context, fungal diseases are rated as one of the most important factor contributing to yield losses in oilseed crops (Grover and Growthaman, 2003).

Management of Alternaria blight is very much difficult and requires frequent fungicidal sprays. Host resistance is one of the important components of integrated disease management. The regular appearance of this disease with no apparent resistance among the related varieties of Indian mustard warrants immediate attention for the control of the disease. Skoropad and Tewari (1977) reported that among the oilseed brassicas species, B. juncea and B. rapa are susceptible to Alternaria blight. Kolte et.al. (2000) reported that dwarf $B$. juncea var. Divya showed tolerance against $A$. brassicae. Management of Alternaria blight is being performed mainly by two approaches; first by healthy seeds, a balanced nutrition, proper field sanitation, destruction of diseased debris and crop rotation. Seed treatment with hot water at $50^{\circ} \mathrm{c}$ for $20-25$ minutes also eliminates seed born inoculums (Aneja and Agnihotri, 2013). Second and most extensively used approach is chemical control by application of fungicides.

Keeping in view the economic value of the crop for the region and extensive damaged caused by Alternaria blight, the present study, was conducted to find out the suitable management strategy against the Alternaria blight pathogens.

\section{Materials and Methods}

Extensive survey of rapeseed-mustard growing areas of Jammu Division was conducted during 2015-16 to monitor the prevalence and status of Alternaria blight of mustard for which three districts viz. Jammu, Samba and Kathua were selected on the basis of their area and under the cultivation of the crop. Three villages in each district were identified and three fields of every village were marked for assaying the status of the disease. In each field, five spots $(2.0 \times 2.0 \mathrm{~m})$ were identified by stratified random sampling. The disease intensity was recorded using quadrant $\left(1 \mathrm{~m}^{2}\right)$ at $4-5$ spots in each field. Randomly five plants were selected and tagged for taking observations. Ten leaves and ten pods per plant were taken from different plant parts for scoring disease intensity. The overall scoring was done at 0-5 
rating scale on the basis of disease assessment key for Alternaria blight in rapeseed-mustard proposed by Conn et al., (1990).

Further PDI shall be calculated by using the following formulae:

Per cent disease intensity $=\frac{\text { Sum of all numerical ratings }}{\text { Number of plants examined } \times \text { Maximum disease rating }} \times 100$

Thirty B. juncea genotypes were obtained from AICRP (R/M), Division of Plant Breeding and Genetics SKUAST- Jammu and were raised in triplicate in rows of 3 meter length with a susceptible check of Varuna (two rows) after each five rows of screened genotypes. The trial was flanked with susceptible check (Varuna) for buildup of large number of inoculums. Experiment field where rapeseed-mustard was grown during the previous years was used for the present investigation. The crop spacing maintained was 30x10 cm following standard package of practice (Anonymous, 2007). Randomly five plants from each row were selected and tagged for recording the further observations for initial appearance of the disease symptoms and per cent disease intensity at 75 and 100 days after sowing.

The field experiment was conducted during the year 2015-16 at the Plant Pathological Research Farm, Chatha. Treatments were laid out in the plots of $(4 \times 1.5 \mathrm{~m})$ in Randomized block design (RBD) with three replications. Two varieties: first, commercially cultivated Varuna $\left(\mathrm{V}_{1}\right)$ and second one tolerant to Alternaria blight RSPR-03 $\left(\mathrm{V}_{2}\right)$ were sown at different dates of sowing viz. $\mathrm{D}_{1}$ (Last week of October), $\mathrm{D}_{2}$ (Second week of November) and $\mathrm{D}_{3}$ (Last week of November) with three plant protection treatments viz. $\mathrm{P}_{1}$ (Seed treatment with Mancozeb @ $2.5 \mathrm{~g} / \mathrm{kg}$ seed), $\mathrm{P}_{2}$ (Seed treatment with Mancozeb @ $2.5 \mathrm{~g} / \mathrm{kg}$ seed + foliar spray of Mancozeb @ $0.25 \%$ on appearance of disease and $\mathrm{P}_{0}$ (Unprotected). The seeds were sown in the field with row to row distance of $30 \mathrm{~cm}$ and plant to plant distance of $10 \mathrm{~cm}$ with 195 plants per plot. Thinning and weeding of the crop was done whenever it was found to be necessary. All the agronomical practices were followed as per the package of practices of the SKUASTJammu. Data on disease intensity was recorded time to time. Yield per plot was also taken for the analysis and to know the effect of each treatment on yield of the crop.

\section{Results and Discussion}

To assess the status of Alternaria blight of rapeseed-mustard in different districts of Jammu division, an extensive survey was conducted during 2015-16 at different villages of district Kathua, Samba and Jammu. The data presented in the table 1 revealed that disease was encountered in all the locations surveyed at 75 days after sowing (DAS) and 100 DAS. The overall per cent disease intensity (PDI) at leaf stage at 75DAS ranged from 28.90 to 44.13. Maximum disease intensity was observed in Chatha $(44.13 \%)$ followed by Akhnoor (41.20\%) while minimum disease intensity was recorded in the village Gudwal (28.90\%). However, PDI on leaf at 100 DAS ranged from 35.20 to 50.80. Maximum disease intensity on leaf at 100 DAS was observed in Chatha $(50.80 \%)$ followed by Akhnoor (50.26\%). The minimum disease intensity was observed in the village Gudwal (35.20\%). Similarly, overall PDI on pods at 75 DAS ranged from 12.60 to 22.40 . The maximum disease intensity on pods was recorded at the village Chatha $(22.40 \%)$ at 75 DAS and minimum in village Gudwal (12.60\%). However, PDI on pods at 100 DAS ranged from 19.30 to 32.26. The maximum disease intensity on pods was observed in Chatha (32.26\%) and minimum in Gudwal $(19.30 \%)$ at 100 DAS.

The data also revealed that maximum disease intensity on leaf and on pod at 75DAS and 100DAS was observed from Jammu (40.13\% and $49.90 \%$ on leaves and 20.70 and 29.30 on 
pods) followed by Kathua $(32.92 \%$ and $44.48 \%$ on leaves and $16.40 \%$ and $27.07 \%$ on pods), respectively. However, Samba district recorded least disease intensity $29.58 \%$ and $40.35 \%$ on leaves and at pods it was $13.70 \%$ and $22.63 \%$ at 75DAS and 100DAS, respectively. The per cent disease intensity was higher in Jammu and Kathua districts as compared to Samba district it may be due to variation in environmental conditions, land topography and irrigation facilities, and thus may results in huge loss in yield. In Jammu and Kathua districts, irrigation facilities are better as compared to district Samba. Similar findings have also been advocated by Chattopadhyay et al., (2005) during his study that Alternaria blight was favoured by high humidity, rain fall, decrease in maximum and minimum temperature and sunshine hours. Losses due to this disease have been reported from India and world by different workers. Losses ranging from 15.0 to 71.0 per cent in rapeseed-mustard has been recorded by Kadian and Saharan, (1983) and Ram and Chouhan, (1998). Kolte, (1985) reported 10.0 to 75.0 per cent losses in yield of oilseed crops from India. In addition to direct yield losses, the disease adversely affects the seed quality by reducing seed size, seed discoloration and reduction in oil content (Kaushik et al., 1984). Hong et al., (1996) reported that Alternaria blight results in yield losses up to 71.4 per cent.

Average yield loss in the range of 32-57 per cent due to Alternaria blight has been reported from Nepal (Shrestha et al., 2005). Besides India, disease is reported to be of major economic importance in Australia, France and Poland and of moderate importance in Canada and United Kingdom (Sharma and Kolte, 1994; Verma and Saharan, 1994; Barman and Bhagavati, 1995).

It is evident from the data presented in table 2 that all the genotypes exhibited moderately resistant to highly susceptible disease reaction against Alternaria blight which recorded 23.8 to 78.5 per cent disease intensity on leaves and 15.8 to 76.5 PDI on pods at 100 DAS. Data of 75DAS and 100DAS exhibited maximum PDI on Varuna which was as par with Kranti followed by SKM-1027. The minimum PDI on leaves (23.8) and on pods (15.8) was observed on the genotype RSPR03. It was followed by KM-108 where PDI was 24.2 and 16.5 on leaves and pods, respectively after 100DAS.

Of the genotypes screened, four genotypes viz. KM-108, DRMRIJ-31, RSPR-03 and NRCDR-101 showed moderately resistant disease reaction at 75DAS and 100DAS with PDI (11.0-25.0\%). Sixteen genotypes viz. RB78, NML-42, TM-108, PR-2012-4, SKM1208, KMR-14-4, Rohini, RSPR-69, RRN772, RRN-778, Divya-55, KMR-13-4, NPJ179, NPJ-180, TM-106-1 and Novgold were found to be moderately susceptible with PDI (26.0-50.0\%) while seven genotypes i.e. TM204, RMM-09-1-1, KMR-13-3, DRMR-67539, RGN-329, RH-0761 and RH-0923 were found to be susceptible recording a disease intensity (51.0-75.0\%) on leaves and pods at 75DAS and 100DAS. However, three genotypes viz. Varuna, Kranti and SKM-1027 were found to be highly susceptible to Alternaria blight recording a disease intensity of more than $75 \%$ at 75DAS and 100DAS.

Thirty genotypes were procured from AICRP (R/M), Division of Plant Breeding and Genetics, SKUAST-Jammu and evaluated for their reaction against Alternaria blight to find out the resistant sources. During the experiment it was found that none of the genotype was resistant to the disease. Out of all the genotypes screened four genotypes viz. RSPR-03, KM-108, DRMRIJ-31 and NRCDR-101 showed moderately resistance. Sources of resistance to the disease have been identified in wild and related species of Brassicas. For instance, Sinapis alba, commonly known as white mustard (Hansen 
and Earle, 1997), Camelina sativa, Eruca sativa (Tewari and Conn, 1993), Diplotaxis species (Sharma et al., 2002) and B. maurorum (Chrungu et al., 1999). Dang et al., (2000) has reported that genotypes viz. DIR1507 and DIR-1522 of B. juncea had stable resistance against Alternaria blight. Fifty four lines/varieties were tested by Srivastva et al., (2001) in an Alternaria sick plot and observed that none of the varieties were resistant to Alternaria blight. Kumar, (2008) reported partial resistance in three genotypes of $B$. juncea viz. Kranti, PR-8988 and PR-9024. Kolte et al., (2008) also reported B. juncea strains EC-399296, EC-399299, EC-399301 and EC-399313 have shown tolerance to Alternaria blight. Singh et al., (2009) at N.D. University of Agriculture and Technology, Faizabad screened 81 lines of Indian mustard against Alternaria blight under natural epiphytotics conditions and reported that none of the genotype was completely free from visible symptoms of the disease. Only YET25 was fairly resistant, however, 10 lines were moderately resistant. Mondal, (2008) tested various varieties and reported that Jhumkta,
Sanjuka, Aseech, Seeta and Bhaigirathi found to be better and could be recommended. Rahman et al., (2010) found varying degree of disease severity while evaluating 26 lines of rapeseed-mustard during the extensive research on Alternaria blight at RARS, Jamalpur. On the basis of disease index he observed that none of the lines was highly resistant or resistant, while six lines among them appeared to be moderately resistant to Alternaria blight. All these above reports show confirmation for our results. It can be concluded that use of germplasm which showed resistance to Alternaria blight during the present studies may be utilized in future resistance breeding programme and reduce disease intensity as well as spread under Jammu conditions and thereby minimize the losses incurred by farmers to Alternaria blight of rapeseed-mustard.

The minimum disease intensity $(20.0 \%)$ was recorded in variety RSPR-03 coupled with $26^{\text {th }}$ October of sowing and seed treatment with mancozeb @ 2.5g/kg + foliar spray of mancozeb@ $0.25 \%$ on appearance of disease.

\begin{tabular}{|l|l|l|l|}
\hline Category & Numerical value & Criteria & Disease reaction \\
\hline I & 0 & Healthy & Disease free \\
\hline II & 1 & $1-10 \%$ leaf area infected & Resistant \\
\hline III & 2 & $11-25 \%$ leaf area infected & Moderately resistant \\
\hline IV & 3 & $26-50 \%$ leaf area infected & Moderately susceptible \\
\hline V & 4 & $51-75 \%$ leaf area infected & Susceptible \\
\hline VI & 5 & $>75 \%$ leaf area infected & Highly susceptible \\
\hline
\end{tabular}

Thirty B. juncea genotypes which were screened as follows
1. Varuna
2. Kranti
5. TM- 108
6. PR-2012-4
3. RB-78
4. NML- 42
9. DRMRIJ-31
10. KMR-14-4
7. SKM-1208
8. KM-108
13. TM-204
14. KMR-13-3
11. Rohini
12. RMM-09-1-1
17. RSPR-03
18. NRCDR-101
15. DRMR-675-39
16. RGN-329
21.RRN-778
22. Divya-55
19.RSPR-69
20. RRN-772
25. RH-0923
26. KMR-13-4
23. RH-0761
24. SKM-1027
29. TM-106-1
30. Novgold
27. NPJ-179
28. NPJ-180 


\section{The treatment details are as follows}

$\mathrm{T}_{1}-$ Varuna $+26^{\text {th }}$ October of sowing + seed treatment with mancozeb @ $2.5 \mathrm{~g} / \mathrm{kg}$ seed $\left(\mathrm{V}_{1} \mathrm{D}_{1} \mathrm{P}_{1}\right)$

$\mathrm{T}_{2}-$ Varuna $+26^{\text {th }}$ October of sowing + seed treatment with mancozeb @ $2.5 \mathrm{~g} / \mathrm{kg}$ seed + foliar spray of mancozeb on appearance of disease @ $0.25 \%\left(\mathrm{~V}_{1} \mathrm{D}_{1} \mathrm{P}_{2}\right)$

$\mathrm{T}_{3}-$ Varuna $+26^{\text {th }}$ October of sowing + unprotected $\left(\mathrm{V}_{1} \mathrm{D}_{1} \mathrm{P}_{0}\right)$

$\mathrm{T}_{4}-$ Varuna $+14^{\text {th }}$ November of sowing + seed treatment with mancozeb @ $2.5 \mathrm{~g} / \mathrm{kg}$ seed $\left(\mathrm{V}_{1} \mathrm{D}_{2} \mathrm{P}_{1}\right)$

$\mathrm{T}_{5}-$ Varuna $+14^{\text {th }}$ November of sowing + seed treatment with mancozeb @ $2.5 \mathrm{~g} / \mathrm{kg}$ seed + foliar spray of mancozeb on appearance of disease @ $0.25 \%\left(\mathrm{~V}_{1} \mathrm{D}_{2} \mathrm{P}_{2}\right)$

$\mathrm{T}_{6}-$ Varuna $+14^{\text {th }}$ November of sowing + unprotected $\left(\mathrm{V}_{1} \mathrm{D}_{2} \mathrm{P}_{0}\right)$

$\mathrm{T}_{7}-$ Varuna $+27^{\text {th }}$ November of sowing + seed treatment with mancozeb @ $2.5 \mathrm{~g} / \mathrm{kg}$ seed $\left(\mathrm{V}_{1} \mathrm{D}_{3} \mathrm{P}_{1}\right)$

$\mathrm{T}_{8}-$ Varuna $+27^{\text {th }}$ November of sowing + seed treatment with mancozeb @ $2.5 \mathrm{~g} / \mathrm{kg}$ seed + foliar spray of mancozeb on appearance of disease @ $0.25 \%\left(\mathrm{~V}_{1} \mathrm{D}_{3} \mathrm{P}_{2}\right)$

$\mathrm{T}_{9}-$ Varuna $+27^{\text {th }}$ November of sowing + unprotected $\left(\mathrm{V}_{1} \mathrm{D}_{3} \mathrm{P}_{0}\right)$
$\mathrm{T}_{10}-\mathrm{RSPR}-03+26^{\text {th }}$ October of sowing + seed treatment with mancozeb @ $2.5 \mathrm{~g} / \mathrm{kg}$ seed $\left(\mathrm{V}_{2} \mathrm{D}_{1} \mathrm{P}_{1}\right)$

$\mathrm{T}_{11}-\mathrm{RSPR}-03+26^{\text {th }}$ October of sowing + seed treatment with mancozeb @ $2.5 \mathrm{~g} / \mathrm{kg}$ seed + foliar spray of mancozeb on appearance of disease @ $0.25 \%\left(\mathrm{~V}_{2} \mathrm{D}_{1} \mathrm{P}_{2}\right)$

$\mathrm{T}_{12}-\mathrm{RSPR}-03+26^{\text {th }}$ October of sowing + unprotected $\left(\mathrm{V}_{2} \mathrm{D}_{1} \mathrm{P}_{0}\right)$

$\mathrm{T}_{13}-\mathrm{RSPR}-03+14^{\text {th }}$ November of sowing + seed treatment with mancozeb @ $2.5 \mathrm{~g} / \mathrm{kg}$ seed $\left(\mathrm{V}_{2} \mathrm{D}_{2} \mathrm{P}_{1}\right)$

$\mathrm{T}_{14}-\mathrm{RSPR}-03+14^{\text {th }}$ November of sowing + seed treatment with mancozeb @ $2.5 \mathrm{~g} / \mathrm{kg}$ seed + foliar spray of mancozeb on appearance of disease @ $0.25 \%\left(\mathrm{~V}_{2} \mathrm{D}_{2} \mathrm{P}_{2}\right)$

$\mathrm{T}_{15}-\mathrm{RSPR}-03+14^{\text {th }}$ November of sowing + unprotected $\left(\mathrm{V}_{2} \mathrm{D}_{2} \mathrm{P}_{0}\right)$

$\mathrm{T}_{16}-\mathrm{RSPR}-03+27^{\text {th }}$ November of sowing + seed treatment with mancozeb @ $2.5 \mathrm{~g} / \mathrm{kg}$ seed $\left(\mathrm{V}_{2} \mathrm{D}_{3} \mathrm{P}_{1}\right)$

$\mathrm{T}_{17}-\mathrm{RSPR}-03+27^{\text {th }}$ November of sowing + seed treatment with mancozeb @ $2.5 \mathrm{~g} / \mathrm{kg}$ seed + foliar spray of mancozeb on appearance of disease @ $0.25 \%\left(\mathrm{~V}_{2} \mathrm{D}_{3} \mathrm{P}_{2}\right)$

$\mathrm{T}_{18}-\mathrm{RSPR}-03+27^{\text {th }}$ November of sowing + unprotected $\left(\mathrm{V}_{2} \mathrm{D}_{3} \mathrm{P}_{0}\right)$ 
Table.1 Per cent disease intensity of Alternaria blight of rapeseed -mustard in Different districts of Jammu Division

\begin{tabular}{|c|c|c|c|c|}
\hline \multirow[t]{3}{*}{ Location } & \multicolumn{4}{|c|}{ Per cent disease intensity } \\
\hline & \multicolumn{2}{|c|}{ Leaf } & \multicolumn{2}{|c|}{ Pod } \\
\hline & 75 DAS* & 100 DAS & 75 DAS & 100 DAS \\
\hline \multicolumn{5}{|l|}{ Kathua } \\
\hline Chadwal & 30.80 & 42.20 & 15.30 & 23.10 \\
\hline Lakhri & 34.50 & 46.60 & 17.30 & 30.66 \\
\hline Deoli & 33.46 & 44.66 & 16.60 & 27.46 \\
\hline Range & 30.80 to 34.50 & 42.20 to 46.60 & 15.30 to 17.30 & 23.10 to 30.66 \\
\hline Mean S.E $(m) \pm$ & $32.92 \pm 1.10$ & $44.48 \pm 1.27$ & $16.40 \pm 0.58$ & 27.07 to 2.19 \\
\hline \multicolumn{5}{|l|}{ Samba } \\
\hline Sangwal & 29.30 & 38.80 & 13.30 & 24.00 \\
\hline Gudwal & 28.90 & 35.20 & 12.60 & 19.30 \\
\hline Gho-Rakhwala & 30.54 & 47.06 & 15.20 & 24.60 \\
\hline Range & 28.90 to 30.54 & 35.20 to 47.06 & 12.60 to 15.20 & 19.30 to 24.60 \\
\hline Mean SE $(m) \pm$ & $29.58 \pm 0.49$ & $40.35 \pm 3.51$ & $13.70 \pm 0.77$ & $22.63 \pm 1.67$ \\
\hline \multicolumn{5}{|l|}{ Jammu } \\
\hline Rapper & 35.06 & 48.66 & 18.92 & 26.60 \\
\hline Akhnoor & 41.20 & 50.26 & 20.80 & 29.06 \\
\hline Chatha & 44.13 & 50.80 & 22.40 & 32.26 \\
\hline Range & 35.06 to 44.13 & 48.66 to 50.80 & 18.92 to 22.40 & 26.60 to 32.26 \\
\hline Mean SE $(m) \pm$ & $40.13 \pm 2.67$ & $49.90 \pm 0.64$ & $20.70 \pm 1.00$ & $29.30 \pm 1.63$ \\
\hline Overall range & 28.90 to 44.13 & 35.20 to 50.80 & 12.60 to 22.40 & 19.30 to 32.26 \\
\hline Grand mean SE $(m) \pm$ & $34.21 \pm 1.77$ & $44.96 \pm 1.78$ & $16.93 \pm 1.09$ & $26.33 \pm 1.34$ \\
\hline
\end{tabular}

DAS* - Days after sowing 
Table.2 Disease reaction of different $B$. juncea genotypes against Alternaria blight pathogens under natural conditions

\begin{tabular}{|c|c|c|c|c|c|c|c|}
\hline \multirow[t]{3}{*}{ Genotype } & \multirow{3}{*}{$\begin{array}{c}\text { Initial } \\
\text { appearance of } \\
\text { the } \\
\text { disease(DAS) }\end{array}$} & \multicolumn{6}{|c|}{ Per cent disease intensity } \\
\hline & & \multicolumn{3}{|c|}{ Leaves } & \multicolumn{3}{|c|}{ Pods } \\
\hline & & $\begin{array}{c}75 \\
\text { DAS }\end{array}$ & $\begin{array}{l}100 \\
\text { DAS }\end{array}$ & $\begin{array}{c}\text { Disease } \\
\text { Reaction }\end{array}$ & $\begin{array}{c}75 \\
\text { DAS }\end{array}$ & $\begin{array}{l}100 \\
\text { DAS }\end{array}$ & $\begin{array}{c}\text { Disease } \\
\text { Reaction }\end{array}$ \\
\hline Varuna & 40 & 52.8 & 78.5 & HS & 45.4 & 76.5 & HS \\
\hline Kranti & 42 & 50.5 & 77.7 & HS & 47.8 & 75.2 & HS \\
\hline $\mathrm{RB}-78$ & 44 & 35.6 & 48.4 & MS & 25.5 & 36.8 & MS \\
\hline NML -42 & 43 & 37.8 & 48.6 & MS & 25.6 & 38.5 & MS \\
\hline $\mathrm{TM}-108$ & 45 & 38.5 & 49.6 & MS & 25.8 & 37.6 & MS \\
\hline PR-2012-4 & 50 & 29.2 & 45.4 & MS & 18.5 & 27.8 & MS \\
\hline SKM-1208 & 44 & 38.5 & 47.6 & MS & 26.2 & 36.4 & MS \\
\hline KM-108 & 54 & 17.6 & 24.2 & MR & 10.8 & 16.5 & MR \\
\hline DRMRIJ-31 & 53 & 17.8 & 24.6 & MR & 12.6 & 18.2 & MR \\
\hline KMR-14- 4 & 45 & 34.2 & 43.8 & MS & 23.8 & 29.6 & MS \\
\hline Rohini & 48 & 36.4 & 45.4 & MS & 20.5 & 32.4 & MS \\
\hline RMM-09-1-1 & 42 & 44.6 & 62.2 & $S$ & 32.6 & 51.5 & $\mathrm{~S}$ \\
\hline TM-204 & 43 & 40.4 & 60.8 & $S$ & 28.8 & 50.4 & $S$ \\
\hline KMR-13-3 & 43 & 39.2 & 59.5 & $S$ & 29.5 & 50.8 & $S$ \\
\hline DRMR-675-39 & 42 & 44.2 & 61.8 & $S$ & 30.8 & 51.2 & $S$ \\
\hline RGN-329 & 42 & 40.8 & 61.5 & $S$ & 29.5 & 50.4 & $S$ \\
\hline RSPR-03 & 56 & 17.8 & 23.8 & MR & 9.6 & 15.8 & MR \\
\hline NRCDR-101 & 54 & 18.2 & 24.4 & MR & 10.4 & 18.5 & MR \\
\hline RSPR-69 & 47 & 30.8 & 43.5 & MS & 20.8 & 30.6 & MS \\
\hline RRN - 772 & 48 & 35.5 & 48.4 & MS & 23.6 & 36.8 & MS \\
\hline RRN - 778 & 46 & 34.6 & 46.8 & MS & 24.8 & 34.4 & MS \\
\hline Divya -55 & 48 & 32.8 & 45.6 & MS & 22.6 & 34.8 & MS \\
\hline RH- 0761 & 45 & 40.8 & 61.6 & $S$ & 26.4 & 50.5 & $\mathrm{~S}$ \\
\hline SKM-1027 & 44 & 53.2 & 76.5 & HS & 47.6 & 75.8 & HS \\
\hline RH- 0923 & 46 & 40.8 & 61.7 & $S$ & 28.5 & 50.8 & $S$ \\
\hline KMR- 13-4 & 48 & 32.6 & 43.8 & MS & 20.5 & 30.4 & MS \\
\hline NPJ -179 & 49 & 27.8 & 38.6 & MS & 15.6 & 26.8 & MS \\
\hline NPJ -180 & 50 & 27.4 & 36.8 & MS & 16.2 & 25.2 & MS \\
\hline TM-106-1 & 46 & 30.8 & 41.6 & MS & 16.5 & 27.8 & MS \\
\hline Novgold & 52 & 28.5 & 39.8 & MS & 16.2 & 26.6 & MS \\
\hline
\end{tabular}

DAS - Days after sowing
Disease free- Immune, 1-10\% -Resistant, 11-25\% -Moderately resistant, 26-50\% - Moderately susceptible, 51-75\% Susceptible, $>75 \%$ - Highly susceptible 
Table.3 Integrated management of Alternaria blight of rapeseed-mustard

\begin{tabular}{|c|c|c|c|}
\hline \multicolumn{2}{|c|}{ Treatments } & \multirow{2}{*}{$\begin{array}{c}\text { Disease intensity (\%) } \\
44.00\end{array}$} & \multirow{2}{*}{$\begin{array}{c}\text { Yield (q/ha.) } \\
13.00\end{array}$} \\
\hline $\mathrm{T}_{1}$ & $\mathrm{~V}_{1} \mathrm{D}_{1} \mathrm{P}_{1}$ & & \\
\hline $\mathrm{T}_{2}$ & $\mathrm{~V}_{1} \mathrm{D}_{1} \mathrm{P}_{2}$ & 36.00 & 14.00 \\
\hline $\mathrm{T}_{3}$ & $\mathrm{~V}_{1} \mathrm{D}_{1} \mathrm{P}_{0}$ & 54.50 & 12.50 \\
\hline $\mathrm{T}_{4}$ & $\mathrm{~V}_{1} \mathrm{D}_{2} \mathrm{P}_{1}$ & 52.50 & 11.30 \\
\hline $\mathrm{T}_{5}$ & $\mathrm{~V}_{1} \mathrm{D}_{2} \mathrm{P}_{2}$ & 45.00 & 12.80 \\
\hline $\mathrm{T}_{6}$ & $\mathrm{~V}_{1} \mathrm{D}_{2} \mathrm{P}_{0}$ & 62.50 & 10.20 \\
\hline $\mathrm{T}_{7}$ & $\mathrm{~V}_{1} \mathrm{D}_{3} \mathrm{P}_{1}$ & 58.00 & 09.75 \\
\hline $\mathrm{T}_{8}$ & $\mathrm{~V}_{1} \mathrm{D}_{3} \mathrm{P}_{2}$ & 55.50 & 10.50 \\
\hline $\mathrm{T}_{9}$ & $\mathrm{~V}_{1} \mathrm{D}_{3} \mathrm{P}_{0}$ & 68.50 & 08.50 \\
\hline $\mathrm{T}_{10}$ & $\mathrm{~V}_{2} \mathrm{D}_{1} \mathrm{P}_{1}$ & 26.00 & 12.20 \\
\hline $\mathrm{T}_{11}$ & $\mathrm{~V}_{2} \mathrm{D}_{1} \mathrm{P}_{2}$ & 20.00 & 12.50 \\
\hline $\mathrm{T}_{12}$ & $\mathrm{~V}_{2} \mathrm{D}_{1} \mathrm{P}_{0}$ & 32.00 & 10.80 \\
\hline $\mathrm{T}_{13}$ & $\mathrm{~V}_{2} \mathrm{D}_{2} \mathrm{P}_{1}$ & 46.00 & 09.90 \\
\hline $\mathrm{T}_{14}$ & $\mathrm{~V}_{2} \mathrm{D}_{2} \mathrm{P}_{2}$ & 38.50 & 10.80 \\
\hline $\mathrm{T}_{15}$ & $\mathrm{~V}_{2} \mathrm{D}_{2} \mathrm{P}_{0}$ & 48.00 & 09.00 \\
\hline $\mathrm{T}_{16}$ & $\mathrm{~V}_{2} \mathrm{D}_{3} \mathrm{P}_{1}$ & 47.50 & 08.20 \\
\hline $\mathrm{T}_{17}$ & $\mathrm{~V}_{2} \mathrm{D}_{3} \mathrm{P}_{2}$ & 42.40 & 09.60 \\
\hline $\mathrm{T}_{18}$ & $\mathrm{~V}_{2} \mathrm{D}_{3} \mathrm{P}_{0}$ & 53.00 & 07.20 \\
\hline & m) \pm & 0.946 & 0.47 \\
\hline & $(P=0.05)$ & 2.73 & 1.36 \\
\hline
\end{tabular}


It was followed by RSPR-03 coupled with $26^{\text {th }}$ October of sowing and seed treatment with mancozeb where $26.0 \%$ disease intensity was recorded. However, maximum disease intensity $(68.5 \%)$ was observed in variety Varuna coupled with $27^{\text {th }}$ November of sowing where no plant protection measure was adopted.

Similarly, table 3 also revealed that highest yield $(14.0 \mathrm{q} / \mathrm{ha})$ was recorded in the variety Varuna coupled with $26^{\text {th }}$ October of sowing and seed treatment with mancozeb @ $2.5 \mathrm{~g} / \mathrm{kg}$ seed + foliar spray of mancozeb @ $0.25 \%$ on the appearance of disease and it was significantly superior among all the treatments. It was followed by variety Varuna coupled with $26^{\text {th }}$ October of sowing and seed treatment with mancozeb @ 2.5g/kg seed where $13.0 \mathrm{q} / \mathrm{ha}$ yield was obtained. However, minimum yield $7.20 \mathrm{q} / \mathrm{ha}$ was recorded in the variety RSPR-03 coupled with $27^{\text {th }}$ November of sowing where no plant protection measures were adopted.

Among the 18 treatment in integrated disease management, it was observed that variety RSPR-03 coupled with $26^{\text {th }}$ October of sowing + seed treatment with mancozeb @ $2.5 \mathrm{~g} / \mathrm{kg}$ seed + foliar spray of mancozeb @ $0.25 \%$ on appearance of disease symptoms showed minimum disease intensity $(20.0 \%)$. However, maximum disease intensity $(68.50 \%)$ was observed for the variety Varuna in case of unprotected condition and last date of sowing i.e. $27^{\text {th }}$ November.

Maximum yield (14.00 q/ha) was recorded from the variety Varuna coupled with $26^{\text {th }}$ October of sowing + seed treatment with mancozeb@2.5 g/kg seed + foliar spray of mancozeb @ 0.25\% on appearance of disease symptoms. However, minimum yield (7.20 $\mathrm{q} / \mathrm{ha}$ ) was recorded for the variety RSPR-03 in case of unprotected conditions and last date of sowing i.e. 27 November.
Early October sowing (Kolte, 1985) balanced NPK application $\mathrm{N}_{100} \mathrm{P}_{40} \mathrm{~K}_{40}$ (Sharma and Kolte, 1994) and sanitation are the important top priority practices in the management of Alternaria blight. The increase in infection rate of Alternaria blight is directly proportional to delay in planting of the crop.

Use of early maturing varieties allows disease escape mechanism. Seed treatment alone will not give sufficient persistence for the control of Alternaria blight (Kolte et al., 2000).

Early sowing of well stored clean certified seeds, timely weeding, maintenance of optimum plant protection and avoidance of irrigation at flowering and pod formation stages may help to manage the disease (Meena et al., 2002). Mancozeb was the best among all treatments resulting in lowest disease severity on leaves of mustard (Meena et al., 2004). Integration of all the best components comprising early sowing, resistant genotypes, seed treatment and foliar spray of fungicide on appearance of disease provides maximum yield.

Although, disease intensity in Varuna was more than the resistant cultivar RSPR-03 but it gave more yield to that of resistant genotype RSPR-03 because Varuna is agronomically more superior, higher yielding and bearing large number of pods than RSPR03 due to which better grain yield was obtained even from the more disease intensity. Bishwas et al., (2007) reported that Alternaria blight of mustard could be minimized by alternation in date of sowing.

The above results also suggests that Alternaria blight in mustard in rapeseedmustard can be successfully managed by adopting an integrated approach i.e. use of early maturing and disease tolerant variety, early October sowing and need based strategy of fungicide use. 


\section{References}

Aneja, J.K., and Agnihotri A, 2013. Alternaria blight of oilseed brassicas: epidemiology and disease control strategies with special reference to use biotechnological approaches for attaining host resistance. Journal of Oilseed Brassica, 4: 1-10.

Anonymous, 2007. Package of practice for rabi crops. Sher-e-Kashmir University of Agriculture Sciences and Technology, Jammu, pp. 26-29.

Anonymous, 2014. Agricultural statistics at a glance. Agriculture Statistics Division, Department of Agriculture \& Cooperative, Ministry of Agriculture, Government of India, New Delhi, pp. 111-112.

Anonymous, 2015. Directorate of Economics and Statistics, Government of J\&K, India, pp. 63-64.

Barman, B., and Bhagwati R 1995. Assessment of yield losses due to Alternaria brassicae in mustard. Plant Health 1: 80-82.

Biswas, C., Singh R and Tewari R B 2007. Management of white rust (Albugo candida) of mustard (Brassica juncea) by altering sowing date and fungicides. Indian Journal of Agriculture sciences 77: 626628.

Chattopadhyay, C., Agarwal R, Kumar A, Bhar L M, Meena P D, Meena R L, Khan S A, Chattopadhyay A K, Awasthi R P, Singh S N, Chakravarthy N V K, Kumar A, Singh R $\mathrm{B}$ and Bhunia C K 2005. Epidemiology and forecasting of Alternaria blight of oilseed brassica in India a case study. Journal of Plant Diseases and Protection 112: 351365 .

Chrungu, B., Verma N, Mohanty A, Pradhan A and Shivanna K R 1999. Production and characterization of interspecific hybrids between Brassica maurorum and crop brassicas. Theoretical Applied Genetics 98: 608-613.

Conn, K.L., Tewari J P and Awasthi R P 1990. A disease assessment key for Alternaria black spot in rapeseed and mustard. Canadian Plant Disease survey 70: 19-22.

Dang, J.K., Sangwan M S, Mehta N and Kaushik C D 2000. Multiple disease resistance against four fungal foliar diseases of rapeseed-mustard. Indian Phytopathology 53: 455-458.

Grover, A., and Growthaman R 2003. Strategies for development of fungus resistant transgenic plant. Curent Science 84: 3-10.

Hansen, L.H., and Earle E D 1997 Somatic hybrids between Brassica oleracea (L.) and Sinapis alba (L.) with resistance to Alternaria brassicae (Berk) Sacc. Theoretical Applied Genetics 94: 10781085.

Hong, C.X., Fitt B D L and Welham S J 1996. Effect of wetness period and temperature on development of dark pod spot (Alternaria brassicae) on oilseed rape (Brassica napus). Plant Pathology 45: 1077-1089.

Kadian, A.K., and Saharan G S 1983. Symptomology, host range and assessment of yield losses due to Alternaria brassicae infection in rapeseed-mustard. Indian Journal of Mycology and Plant Pathology 13: 319-323.

Kaushik, C.D., Saharan G S and Kaushik J C 1984. Magnitude of loss in yield and management of Alternaria blight in rapeseed-mustard. Indian Phytopathology 37: 398-399.

Kolte, S.J., 1985. Diseases of Annual Edible Oilseed Crops. Volume II, CRC Press, Inc. Boca Raton, Florida, U.S.A, pp. 11.

Kolte, S.J., Awasthi R P and Vishwanath 2000. Divya mustard: A useful source to create Alternaria black spot tolerant dwarf varieties of oilseed brassicas. Plant varieties and Seeds (U. K), 13: 107-111.

Kolte, S.J., Nashaat N I, Kumar A, Awasthi R P and Chouhan J S 2008. Towards improving the genetic base of rapeseed-mustard through an Indo-UK research collaboration. Indian Journal of Plant Genetic Resources 21: 132-137.

Kumar, B., 2008. Assessment of slow blighting (Alternaria brassicae) resistance and yield in Indian mustard (Brassica juncea (L.) Czern. \& Coss.) Indian Phytopathology 61: 171-183.

Kumar, B., and Kolte S J 2001. Progression of Alternaria blight of mustard in relation to components of resistance. Indian Phytopathology 54: 329-331. 
Meena, P.D., Awasthi R P, Chattopadhyay C, Kolte S J and Kumar A 2010. Alternaria blight: a chronic disease in rapeseedmustard. Journal Oilseed Brassica 1: 1-11.

Meena, P.D., Chattopadhyay C, Singh F, Singh B and Gupta A 2002. Yield loss in Indian mustard due to White rust and effect of some cultural practices on Alternaria blight and White rust severity. Brassica 4: 18-24.

Meena, P.D., Meena R L, Chattopadhyay C and Kumar A 2004. Identification of critical stages of disease development and biocontrol of Alternaria blight of Indian mustard (Brassica juncea). Journal of Phytopathology 152: 204-209.

Mondal Goutam, 2008. Evaluation of variety against Alternaria blight and Sclerotinia rot disease of rapeseed-mustard for old alluvial zone of the Northern part of West Bengal. Environment and Ecology 26: 2189-2191.

Rahman, M.M., Elahi FE and Goswami B K 2010. Screening of rapeseed-mustard varieties/lines against Alternaria blight disease. In "Annual Report of Bangladesh Agricultural Research Institute" Gazipur, Bangladesh. pp. 1-2.

Ram, R.S., and Chouhan V B 1998. Assessment of yield losses due to Alternaria leaf spot in various cultivars of mustard and rapeseed. Journal of Mycopathological Research 36: 109-111.

Sharma, G., Kumar V D, Haque A, Bhat S R, Prakash S and Chopra V L 2002. Brassica coenospecies: a rich reservoir for genetic resistance to leaf spot caused by Alternaria brassicae. Euphytica 125: 411- 417.

Sharma, S.R., and Kolte S J 1994. Effect of soil applied NPK fertilizers on severity of black spot disease (Alternaria brassicae) and yield of oilseed rape. Plant and Soil 167: 313-320.

Shrestha, S.K., Munk L and Mathur S B 2005. Role of weather on Alternaria leaf blight disease and its effect on yield and yield components of mustard. Nepal Agriculture Research Journal 6: 62-72.

Singh, V., Kumar K, Bhajan R, Singh P K and Singh R B 2009. Identification of resistance sources against Alternaria blight and white rust in Indian mustard. Journal Oilseed Research 26:435- 436.

Skoropad, W.P., and Tewari J P 1977. Field evaluation of the epicuticular wax in rapeseed and mustard in resistance to Alternaria brassicae. Canadian Journal of Plant Science 57: 1001-1003.

Srivastava, M.P., Mehta N, Sangwan M S and Kumar R 2001. Evaluation of brassica varieties for resistance to Alternaria brassicae (Berk) Sacc. Under epidemic conditions. Tests Agro pp. 22.

Tewari, J.P., and Conn K L 1993. Reaction of some wild crucifers to Alternaria brassicae. Bull OILB SROP 16: 53-58.

Verma, P.R., and Saharan G S 1994. Monograph on Alternaria diseases of crucifers, In "Agriculture and Agricultural food", Saskatoon, Canada, pp. 1-146.

\section{How to cite this article:}

Sandeep Gupta, V.B. Singh, A.K. Singh, S.K. Rai, S.K. Singh and Dwivedi, M.C. 2017. Prevalence, Incidence and Management of Alternaria Blight of Rape-Seed and Mustard (Brassica juncea L) through Resistance and Integrated Approach. Int.J.Curr.Microbiol.App.Sci. 6(9): 2730-2741. doi: https://doi.org/10.20546/ijcmas.2017.609.336 